The value of local organizations in stimulating interest should not be overlooked. A county association was organized in Fairfield County in October, 1918, and Professor Watson, who was then the extension worker with bees, told me that he should not be content until he saw a live organization of beekeepers in each county of the state. Professor Watson has since gone into the Bureau of Entomology, and his successor, Prof. L. B. Crandall, is just beginning his work in the state, and though I have not conferred with him on this point, I am certain from the tone of his paper prepared for this meeting that he will leave no stone unturned to promote the interests of beekeeping within the state.

I have mentioned these conditions in connection with my own state, but no doubt they are common to other states. The welfare of the business demands better beekeepers rather than more of them. With most beekeepers in Connecticut, the keeping of bees is not the chief business but is only a side issue. The few colonies in the average apiary are not enough to warrant a large outlay in time or equipment, and in many cases they do not receive proper treatment. It is believed that the registration of beekeepers, more money for inspection, and the right kind of extension work will make for more intelligent management, and prove a great benefit to the business as a whole.

Chairman W. E. Britron: We will now listen to a paper by Mr. Frank C. Pellett.

Mr. F. C. Pellett: It was accident rather than intention that two subjects were assigned to me on the program. I shall present only one. I might say, incidentally, that Boys' and Girls' Bee Clubs was a subject I chose last year, and I expected to give an outline of some of the things I had observed in localities where such clubs existed.

In Kansas, where a demonstration agent introduced this, especially in the localities where there were no commercial beekeepers, he required parents of each boy or girl who became a member to have bees and they were also required to furnish the club member with the proper equipment for transferring them. One thing especially which attracted my attention was the fact that one farmer made a good deal of fun of one of these boys for taking up these newfangled notions. In the fall of the year, the boy had more honey to sell from his two cells than the farmer had from fifty. The boys' work prospered in that locality from that time on.

My paper is entitled "Adapting System to Locality."

\title{
ADAPTING SYSTEM TO LOCALITY
}

By Frank C. Pellett

Locality is a badly overworked word in our beekeeping literature. 
It is too often used to explain away differences of opinion due to careless observation or improper manipulation. While differences in bee behavior are not usually to be credited to locality, a different system of manipulation is often necessary to make the most of the flows arising under different conditions.

Doctor Phillips and his staff have brought forcibly to the attention of the beekeepers, through the medium of the short courses recently so popular, that the fundamentals of beekeeping are few and easily grasped by the intelligent mind. Room, stores and protection have been shown to constitute the essentials which must be recognized under any conditions. With a proper understanding of these, it then becomes important that the beekeeper study his individual location in order that he may apply his knowledge to bringing his colonies to the peak of brood rearing in time for the principal harvest of the year. In this connection a brief consideration of the peculiar conditions to be met in different parts of the country and the effect upon the plans of the beekeeper may be of some interest.

In southwest Iowa, where the writer kept bees for several years, there was but one principal honey-flow-from white clover. This flow lasted from ten days to six weeks. If the bees were not ready when the flow came there was little chance of securing a crop from a later flow. Usually there was sufficient fall flow to fill the hives and put the bees into good condition for winter, but no surplus worth while was secured. In a location like that the beekeeper must bend every energy of the entire year to bring his bees to maximum strength at the beginning of June and to prevent swarming till the brief flow is over. If the bees winter poorly there is little time for coddling them and building up weaklings to profitable strength. Good wintering is essential. It is also important that no time be lost in building up the colonies in spring. It was found that, by wintering the colonies in two stories with the upper brood-chamber well filled with honey, it was usually possible to turn the surplus of food into young bees and have the two stories well filled with brood and bees by the close of fruit bloom, always providing that the bees wintered well. With careful attention it was possible to get from two to four times as much surplus as the average farmer with bees in the neighborhood was able to secure. There was seldom a season when it was possible to make increase ahead of the honey-flow to any extent, without reducing the crop.

In contrast to this location there are places in the alfalfa districts of Colorado where the main flow comes in August, where it is the practice to make increase from the early flows and still have the bees in good condition for the principal flow. There, some beekeepers practice wintering in two stories and, as soon as the two stories are filled with 
brood in spring, the upper story is removed and given a ripe queen cell. With the late flow it is possible to have two colonies instead of one for the gathering of the crop. In a situation of this kind, poor wintering is not nearly as disastrous, - providing, of course, that the bees come through alive,- as it is where there is only one flow and that very early.

In the vicinity of Washington, D. C., tulip-tree, often spoken of as "poplar," is the principal source. Because it blooms so early that the bees are seldom ready for the flow, the vicinity is generally regarded as a poor location for beekeeping. Yet an average of something like 100 pounds of surplus honey per colony is gathered at the government apiary where careful wintering is practiced.

In the lower Rio Grande Valley of Texas there are frequent flows from many sources. These flows are likely to come at almost any time after a rain. Heavy flows are infrequent and, light flows coming so often, it is difficult for the beekeeper to harvest much surplus, since the honey is largely consumed in the almost continuous brood-rearing. The writer found the bees to be very strong in well-kept apiaries in early March. There were reports, also, that bees sometimes swarmed as late as December and found sufficient support to carry them through. In a location like this, commercial honey production is less profitable than the production of bees and queens to supply the demand of northern beekeepers. In north Texas, at Waxahachie, local beekeepers report that the bees are ready for business by April, yet the main flow does not come till June. They find it very difficult to keep down swarming during the intervening period. One man, T. W. Burleson, has solved this problem by selling his early bees in packages and still giving his colonies time to build up for the honey-flow from cotton. Until the demand for bees developed he found great difficulty in overcoming the swarming problem.

In such locations beekeepers often are very indifferent about giving attention to wintering. They say that no matter how weak the bees are in spring, there is still time to build up in time for the flow and that strong colonies in early spring are of no particular advantage.

There are other factors beside the time of the honey-flow that enter into the consideration of locality. The source and nature of the flows also determine to a great extent the system which is best suited to the conditions. Comb-honey cannot be produced to advantage except under specially favorable conditions. A slow or intermittent flow will result in poorly finished sections and a short crop, where a good crop of extracted honey might be secured. In some sections of Colorado there is much gum-weed (Grindelia squarrosa), which granulates very quickly, sometimes even before the honey is sealed. Where this honey is mixed with the alfalfa, granulation is sure to follow within 
a short time and as a result the comb-honey market gets a black eye. Granulated comb-honey is a drug on the market and in such a situation extracted honey only should be produced. At least comb-honey supers should be replaced with extracting supers during the flow from gum-weed. Enough of this gum-weed alfalfa mixture has gone to eastern markets to create a prejudice against Colorado comb-honey in some places.

In several of the southern states, bitterweed (Helenium tenuifolium) is quite common. The honey is absolutely unpalatable and should never be placed on the market. Even a small quantity of this bitter honey is sufficient to spoil a whole tankful of good honey. There the beekeeper should remove all the good honey from the hive when the bees begin to work on bitterweed and give them empty supers of extracting combs. When the flow is over, if other flows are still to come, the bitter honey can be taken off and the other supers replaced. When the season is over, the bitter honey can be given back to the bees for winter stores. No adverse reports have been found from the use of bitter honey for wintering the bees.

The available pasturage determines the number of colonies that may be successfully kept in one yard and this in turn influences the system of management. In north Georgia there is a large area where not more than twenty-five colonies are profitable in one apiary. There is a variety of sources of nectar available but not enough of anything to support a large number of colonies. One beekeeper in that region keeps 800 colonies of bees, in thirty yards. This requires a large amount of travel, but his returns are more nearly constant than in any other locality with which I am familiar. In contrast there are numerous locations in the sweet clover districts and some in the buckwheat regions where three hundred or more colonies do well in one location.

The presence or absence of a supply of pollen for brood-rearing is also an important factor. In some places, where there are heavy flows, pollen is scarce and the beekeepers find it necessary to take the bees elsewhere to build up. This requires long distance moving which is tiresome and expensive.

The dependability of the forage is also to be considered. There are many places where good crops can be gathered occasionally, with frequent seasons of failure. This necessitates migratory beekeeping if the apiarist is to harvest a crop every year. There are numerous California beekeepers who make long moves from once to three or four times in a season, moving to such locations as promise an immediate harvest. This is practiced to a lesser extent in some of the central and eastern states. The Dadants find it frequently to their advantage to move their apiaries to the lowlands along the Mississippi River 
when the crop is a failure on the uplands. This requires a move of something like thirty miles, which can easily be accomplished in a day, with their big trucks.

The above examples could be multiplied indefinitely, but are sufficient to show how necessary it is that the beekeeper be fully informed as to the conditions peculiar to his location and that he develop a system of beekeeping best adapted to those conditions.

Chatrman W. E. Britton: If there is no discussion, we will take up the next paper, "The Relation of Bees to Fire-Blight," by H. A. Gossard. (Withdrawn for publication elsewhere.)

Chairman W. E. Britron: We will now listen to the paper by Professor J. H. Merrill, entitled "Preliminary Notes on the Value of Winter Protection of Bees," which will be read by Mr. M. C. Tanquary.

Mr. M. C. Tanquary: I am very sorry that Mr. Merrill is not here, because he has spent two years of work on this subject. I have tried to follow him more or less closely, as I was much interested in his work.

\section{PRELIMINARY NOTES ON THE VALUE OF WINTER PROTECTION FOR BEES ${ }^{1}$}

\section{By J. H. MerriLL, A piarist, Kansas State Agricultural College and Experiment Station}

That a strong colony of bees will gather more honey than a weak one is a fact accepted by all experienced beekeepers. However, to gather more honey, this colony should be strong at the proper time in order to take the fullest advantage of the honey-flow. The proper time to have a colony strong is at the beginning of the honey-flow. If it becomes strong too early, it consumes stores which the bees have in the hive; if too late, it cannot assist in gathering the crop for that season. Whether or not the colony is strong will depend to a large extent upon how it passed through the winter.

Gates, 1914, gives some very valuable data on the temperature of the colony of bees throughout the year. Phillips and Demuth, 1914, give the results of some very careful observations on the temperature of a colony of bees in winter, and further explain in detail the actions of such a colony during the winter which are necessary in order to maintain a proper temperature. Phillips maintains that a bee may be compared to a storage battery in that it has a certain amount of energy to spend, after which it dies. He further says that the bee is

\footnotetext{
1 Contribution No. 48 from the Entomological Laboratory, Kansas State Agricultural College. This paper embodies some of the results obtained in the prosecution of project No. 126 of the Agricultural Experiment Station.
} 